\title{
Mortgage Refinancing in 2001 and Early 2002
}

Glenn Canner, Karen Dynan, and Wayne Passmore, of the Board's Division of Research and Statistics, prepared this article. Research assistance was provided by Jennifer Attrep and Gillian Burgess.

In recent years, millions of homeowners in the United States have taken advantage of relatively low interest rates and rising home values to refinance the mortgages on their primary residences. In many cases, refinancing has resulted in a lower interest rate and a reduction in monthly mortgage payments, which have allowed homeowners to spend or save that portion of their incomes no longer dedicated to servicing their mortgage debt. When they have refinanced, many homeowners have liquefied some of the equity they accumulated in their homes by borrowing more than they needed to pay off their former mortgage and cover the transaction costs of the refinancing. They used the funds raised in so-called cash-out refinancings to make home improvements, to repay other debts, or to purchase goods and services or other assets.

Choosing whether, and when, to refinance a home mortgage is a decision that involves a careful balancing of costs and benefits. Some of the factors to be considered are known with certainty and are readily quantifiable; others, such as the future course of interest rates, cannot be known with certainty. A homeowner with a mortgage is more likely to consider refinancing when the current interest rate on mortgages falls below the rate on the homeowner's existing loan. At such times, the homeowner must weigh the prospective after-tax savings from lower monthly payments on a new, lower-rate loan against the after-tax costs of the refinancing transaction itself, including any mortgage fees (points) and application and appraisal fees. Because the savings from lower interest payments accumulate slowly over time as the loan is repaid, the amounts that would be saved in a refinancing must be discounted to their present value and compared with the costs of the transaction, often referred to as the closing costs. ${ }^{1}$ If the amount saved

1. The comparison is not always straightforward, as the homeowner in many instances has a choice of either paying the transaction costs as a lump sum at the time of the refinancing or adding the costs to the amount being refinanced. The cost-benefit comparison is relatively easy in the former case but is more complicated in the latter. To after tax over the long run exceeds the after-tax costs of the transaction, the homeowner stands to gain from the transaction. In addition, homeowners sometimes refinance to raise cash rather than to obtain a lower interest rate or to reduce uncertainty about future payments.

This article presents estimates, based on recent survey findings, of the incidence of refinancing, the changes in terms and conditions of mortgages after refinancing, the amount of funds homeowners raised in the process, and the ways in which homeowners used the funds. It also provides comparisons with previous surveys of refinancing activity and a statistical analysis of the relative importance of different determinants of refinancing and the amount of home equity liquefied during refinancing. Finally, it gives rough estimates of the effects of recent refinancing on the U.S. economy, including the effects on aggregate consumption spending.

\section{SURVEY FINDINGS ON REFINANCING ACTIVITY}

For many years, refinancing activity has been the focus of Board-sponsored surveys of households and of articles in the Federal Reserve Bulletin. ${ }^{2}$ To learn

facilitate the comparison, the after-tax present value of the financed transaction costs must be determined. If the interest rate on the new loan is used as the discount rate in the calculation, the pre-tax present value of the financed transaction costs equals the lump-sum payment today. On an after-tax basis, however, the two amounts may differ. If the transaction costs on a refinancing are financed, the interest paid on those borrowed funds is fully tax-deductible. In contrast, if a lump sum payment of transaction costs is made, only the portion of those costs that constitutes points (prepaid interest) is tax-deductible, and it must be amortized over the life of the loan.

2. The Federal Reserve Board monitors refinancing activity as well as home equity lending, another form of borrowing used to liquefy accumulated equity in homes. Both activities can significantly affect the finances of individual homeowners as well as overall economic activity. See Glenn B. Canner, James T. Fergus, and Charles A. Luckett, "Home Equity Lines of Credit," Federal Reserve Bulletin, vol. 74 (June 1988), pp. 361-63; Glenn B. Canner, Charles A. Luckett, and Thomas A. Durkin, "Home Equity Lending," Federal Reserve Bulletin, vol. 75 (May 1989), pp. 333-44; Glenn B. Canner, Charles A. Luckett, and Thomas A. Durkin, "Mortgage Refinancing," Federal Reserve Bulletin, vol. 76 (August 1990), pp. 604-12; Glenn B. Canner, Charles A. Luckett, and Thomas A. Durkin, "Home Equity Lending: Evidence from Recent Surveys," Federal Reserve Bulletin, vol. 80 (July 1994), pp. 571-83; Glenn B. Canner, Thomas A. Durkin, and Charles A. Luckett, "Recent Developments in Home Equity Lending," Federal Reserve Bulletin, vol. 84 (April 1998), pp. 241-51; and Peter J. Brady, Glenn B. Canner, and Dean M. Maki, "The Effects 
1. Mortgage status and refinancing activity of homeowners

Percent except as noted

\begin{tabular}{|c|c|c|c|c|c|c|}
\hline \multirow[b]{2}{*}{ Item } & \multirow[b]{2}{*}{ Distribution } & \multicolumn{5}{|c|}{ 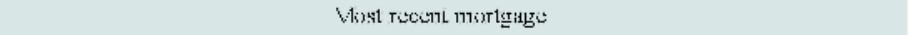 } \\
\hline & & $\begin{array}{c}\text { Mean } \\
\text { interest rate }\end{array}$ & $\begin{array}{l}\text { Mean } \\
\text { mortgage amount } \\
\text { (thousands } \\
\text { of dollars) }\end{array}$ & $\begin{array}{l}\text { Mean } \\
\text { home equity } \\
\text { (thousands } \\
\text { of dollars) }\end{array}$ & $\begin{array}{c}\text { Mean } \\
\text { loan-to-value } \\
\text { ratio }\end{array}$ & $\begin{array}{l}\text { Share of } \\
\text { mortgage } \\
\text { debt }^{1}\end{array}$ \\
\hline Homeowners with mortgages & 62.8 & 7.33 & 100.2 & 110.4 & 54.0 & 100.0 \\
\hline Never refinanced $\quad \ldots . . . \ldots$ & 50.9 & 7.55 & 94.8 & 85.1 & 57.6 & 47.0 \\
\hline Have refinanced. & 49.1 & 7.09 & 105.8 & 135.7 & 50.5 & 52.8 \\
\hline \multicolumn{7}{|l|}{ MEMO: Refinancers } \\
\hline Last refinanced in 2001 or early 2002 & 46.6 & 6.82 & 128.8 & 110.7 & 61.6 & 30.8 \\
\hline Those who took cash out ........... & 44.8 & 6.85 & 125.9 & 104.8 & 62.9 & 13.6 \\
\hline Last refinanced at an earlier time ............. & 53.4 & 7.30 & 84.2 & 159.2 & 40.3 & 21.4 \\
\hline \multicolumn{7}{|c|}{$\begin{array}{l}\text { NotE. All survey data in this and the following tables are based on weighted } \\
\text { observations. } \\
\begin{array}{l}\text { l Percentages may not sum to } 100 \text { because of rounding and a small number } \\
\text { Consumers, University of Michigan Survey Research Center, January } 2002- \\
\text { of missing observations. }\end{array}\end{array}$} \\
\hline
\end{tabular}

more about recent refinancing activity, Fannie Mae and the Federal Reserve sponsored questions concerning mortgage refinancing in the monthly Surveys of Consumers from January through June 2002; these surveys were conducted by the Survey Research Center of the University of Michigan (for details see appendix A). The questions elicited information both on the characteristics of homeowners' current and past mortgages and on the use of funds raised in cash-out refinancings.

\section{The Prevalence of Refinancing}

As of the middle of 2002, about 63 percent of U.S. homeowners had an outstanding mortgage on their primary residence, owing on average about $\$ 100,000$ (table 1). Home mortgage debt is commonly incurred for two reasons. Most homeowners need to borrow funds to finance the purchase of a home. Also, homeowners sometimes borrow against the accumulated equity in their homes to obtain funds to buy goods and services, to repay other debts, or to finance the purchase of financial or nonfinancial assets.

About half of the homeowners with mortgages refinanced at least once after buying their homes. Mortgage refinancing has become a widespread practice in recent years because of a combination of factors, including lower interest rates; the widespread adoption of new technologies that have reduced mortgage transaction costs; and gains in home values and equity, which have increased the opportunities to borrow additional amounts. In addition, the general disappearance of mortgage prepayment penalties during the late 1980 s encouraged refinancing activity.

of Recent Mortgage Refinancing," Federal Reserve Bulletin, vol. 86 (July 2000), pp. 441-50.
Refinancing activity tends to move inversely with changes in interest rates (chart 1). Because interest rates have fluctuated over the past decade or so and have been low relative to the previous two decades, homeowners have had several attractive opportunities to refinance in recent years. Relatively low longterm interest rates in the second half of 2001 and the first half of 2002 stimulated the most recent refinancing boom.

The close link between mortgage interest rates and refinancing makes the time period under consideration important for estimating the amount of refinancing activity (table 2). Our survey asked detailed questions about refinancing during 2001 or the first half of 2002, a period of heavy refinancing activity. During this reference period, mortgage rates fluctuated considerably. As a consequence, the incidence of refinancing is dependent on the time frame within the

\section{Refinancing activity and mortgage rates, 1993-2001}

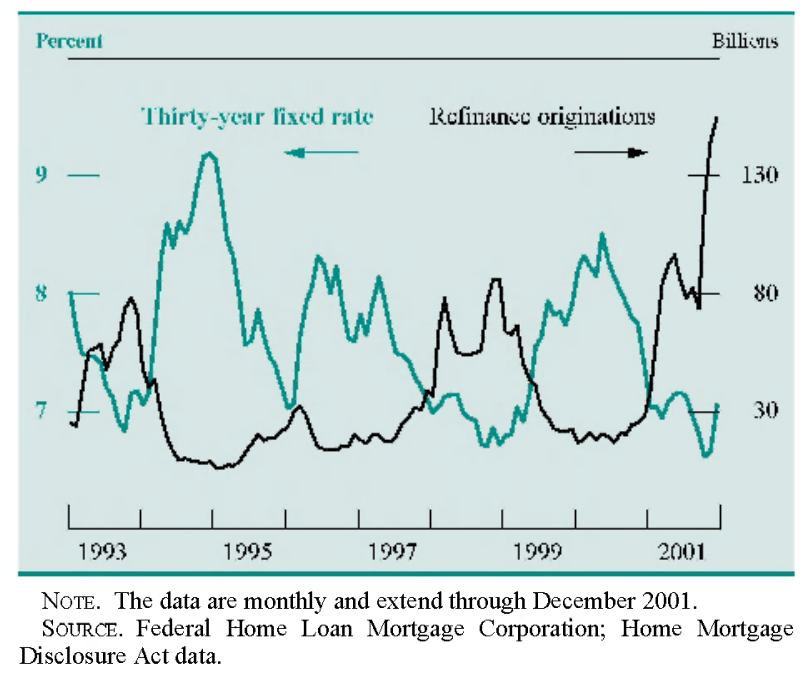


2. Distribution of mortgage refinancers in different periods Percent

\begin{tabular}{|c|c|c|}
\hline Period & $\begin{array}{l}\text { Share of homeowners } \\
\text { with mortgages } \\
\text { who refinanced }\end{array}$ & $\begin{array}{c}\text { Average FHLMC } 30 \text {-year } \\
\text { mortgage rate } \\
\text { (lagged two months) }\end{array}$ \\
\hline \multicolumn{3}{|l|}{2001} \\
\hline January & .69 & 7.75 \\
\hline February & .43 & 7.38 \\
\hline March & 1.00 & 7.03 \\
\hline April & 1.81 & 7.05 \\
\hline May & .77 & 6.95 \\
\hline June & 1.48 & 7.08 \\
\hline July & 1.00 & 7.15 \\
\hline August & 1.26 & 7.16 \\
\hline September & 1.06 & 7.13 \\
\hline October .... & 1.95 & 6.95 \\
\hline November. & 2.14 & 6.82 \\
\hline December. & 1.93 & 6.62 \\
\hline \multicolumn{3}{|l|}{$2002^{1}$} \\
\hline January & 3.32 & 6.66 \\
\hline February & 1.82 & 7.07 \\
\hline March & 1.59 & 7.00 \\
\hline April & 1.25 & 6.89 \\
\hline May & .86 & 7.01 \\
\hline June & .56 & 6.99 \\
\hline \multicolumn{3}{|l|}{$\begin{array}{l}\text { MEMO: Share of } \\
\text { homeowners who } \\
\text { refinanced- }\end{array}$} \\
\hline Before 2001 & 26.24 & . \\
\hline $\begin{array}{l}\text { January- } \\
\text { December } 2001\end{array}$ & $15.81^{\prime}$ & 7.09 \\
\hline $\begin{array}{l}\text { January } 2001- \\
\text { March } 2002\end{array}$ & & \\
\hline $\begin{array}{l}\text { March } 2002 \\
\text { April 2001- }\end{array}$ & 21.40 & 1.05 \\
\hline March 2002 & 19.33 & 6.97 \\
\hline $\begin{array}{l}\text { January } 2001- \\
\text { June } 2002\end{array}$ & 22.87 & 7.04 \\
\hline $\begin{array}{l}\text { In year preceding } \\
\text { survey month }\end{array}$ & 20.20 & 6.99 \\
\hline
\end{tabular}

1 Percentages reflect potential number of respondents who could report they refinanced in a given month.

2 This figure differs slightly from the sum of the percentages for the months in 2001 shown above because some respondents did not provide the month of refinancing.

3 Average mortgage rate for the months that constitute each twelve-month period.

. Not applicable

Source. Federal Home Loan Mortgage Corporation

full reference period. Between 16 percent and 23 percent of homeowners with mortgages reported refinancing since the beginning of 2001, depending on which period is considered (as shown in the memo item of the table). For the entire reference period, the 2002 survey findings suggest that an estimated 11 million homeowners refinanced their mortgages in 2001 or early 2002 .

\section{Refinancing and the Amount of Mortgage Debt}

Homeowners who have refinanced their mortgages tend to have more mortgage debt than those who have not. The survey found that 49 percent of mortgage debt holders had refinanced their loan by 2001 or early 2002 but that these refinancers accounted for 53 percent of outstanding mortgage debt. Refinancers might account for a larger share of the debt because many refinancing homeowners liquefy equity, adding to their debt. Another possibility is that homeowners who have relatively large mortgage balances have a greater propensity to refinance because the potential interest savings are more likely to exceed the transaction costs associated with refinancing. Both of these possibilities are considered later in the article.

\section{Reasons for Refinancing}

As noted, homeowners have various reasons for refinancing their mortgages. These include obtaining a lower interest rate, changing the other terms of their loan (such as converting from an adjustable-rate to a fixed-rate mortgage or shortening or lengthening the repayment period), and liquefying equity. Survey responses from homeowners who refinanced in 2001 and the first half of 2002 provide an opportunity to measure the proportion of homeowners who changed their mortgage circumstances along each of these dimensions.

Because mortgage interest rates were relatively low during the reference period, 96 percent of surveyed homeowners who refinanced over this period obtained a lower rate (table 3 ). The average interest rate for those who refinanced declined 1.83 percentage points, from 8.65 percent to 6.82 percent. Virtually all homeowners who refinanced (over 99 percent) and did not liquefy equity in their homes obtained a lower mortgage rate. Among those extracting equity, about 91 percent also obtained a lower rate.

A number of refinancing homeowners shifted from adjustable-rate mortgages to fixed-rate mortgages when they refinanced (table 4). Nearly three-quarters of the 14 percent of refinancers who had an adjustable-rate mortgage before refinancing switched

3. Interest rates on refinanced loans, 2001 and 2002 Percent

\begin{tabular}{|c|c|c|c|}
\hline Item & $\begin{array}{l}\text { No equity } \\
\text { liquefied }{ }^{1}\end{array}$ & $\begin{array}{l}\text { Equity } \\
\text { liquefied }{ }^{1}\end{array}$ & $\begin{array}{c}\text { All } \\
\text { refinancers }\end{array}$ \\
\hline $\begin{array}{l}\text { Mean interest rate on } \\
\text { old mortgage ......... } \\
\text { Mean interest rate on }\end{array}$ & 8.49 & 8.85 & 8.65 \\
\hline $\begin{array}{l}\text { new mortgage } \\
\text { Difference (percentage points) }\end{array}$ & $\begin{array}{l}6.80 \\
1.69\end{array}$ & $\begin{array}{l}6.85 \\
2.00\end{array}$ & $\begin{array}{l}6.82 \\
1.83\end{array}$ \\
\hline $\begin{array}{l}\text { MEMo } \\
\text { Share of refinancers who lowered } \\
\text { their interest rate } \\
\text { Mean loan-to-value ratio........... }\end{array}$ & $\begin{array}{l}99.5 \\
60.4\end{array}$ & $\begin{array}{l}90.7 \\
62.9\end{array}$ & $\begin{array}{l}95.6 \\
61.6\end{array}$ \\
\hline
\end{tabular}

1 Equity is liquefied when a homeowner refinances mortgage debt and borrows more than is necessary to repay the balance on the existing mortgage(s) plus closing costs on the new loan. 
4. Type of original and refinanced loans and incidence of cash-out among 2001 and 2002 refinancers Percent

\begin{tabular}{|c|c|c|c|}
\hline \multirow{2}{*}{ Type of refinanced loan } & \multicolumn{2}{|c|}{ Type of original loan } & \multirow{2}{*}{ Total } \\
\hline & Adjustable rate & Fixed rate & \\
\hline $\begin{array}{l}\text { Adjustable rate } \\
\text { Fixed rate }\end{array}$ & $\begin{array}{r}4 \\
10\end{array}$ & $\begin{array}{r}9 \\
77\end{array}$ & $\begin{array}{l}13 \\
87\end{array}$ \\
\hline \multirow[t]{2}{*}{ Total . } & 14 & 86 & 100 \\
\hline & \multicolumn{3}{|c|}{ Incitence bf cash-out } \\
\hline $\begin{array}{l}\text { Adjustable rate } \\
\text { Cash-out ...... } \\
\text { No cash-out }\end{array}$ & $\begin{array}{l}62 \\
38\end{array}$ & $\begin{array}{l}55 \\
45\end{array}$ & $\begin{array}{l}57 \\
43\end{array}$ \\
\hline $\begin{array}{l}\text { Fixed rate } \\
\text { Cash-out } \\
\text { No cash-out }\end{array}$ & $\begin{array}{l}46 \\
54\end{array}$ & $\begin{array}{l}44 \\
56\end{array}$ & $\begin{array}{l}44 \\
56\end{array}$ \\
\hline
\end{tabular}

to a fixed-rate loan. However, some of those who originally had a fixed-rate loan shifted to an adjustable-rate product. ${ }^{3}$ The net result was that, after refinancing, the overall proportion of homeowners with an adjustable-rate mortgage changed little.

The propensity to liquefy equity during refinancing differed between those refinancing with a fixed-rate and those refinancing with an adjustable-rate mortgage. Among those taking out an adjustable-rate mortgage, 57 percent extracted equity, whereas of those selecting a fixed-rate mortgage, only 44 percent borrowed additional funds. Homeowners refinancing into an adjustable-rate mortgage spent a greater share of the funds for home improvement, suggesting that they chose an adjustable-rate mortgage either because they desired a lower payment in the short-term or because they might be fixing up their home in anticipation of selling.

Besides reducing their monthly debt service burdens by lowering the interest rate on their loans, refinancing households can also lower the monthly payment by lengthening the term to maturity on their debt. The survey found that most recent-refinancing homeowners lengthened the maturity of their mortgage (table 5). ${ }^{4}$ After refinancing, about 74 percent had mortgages with a longer maturity, mainly because the refinancers chose thirty-year mortgages,

3. Because the interest rates on adjustable-rate mortgages typically start out lower than those on comparable term fixed-rate loans, adjustable-rate mortgages offer a particularly attractive option to those refinancers who expect to sell their home in the near or medium term or who expect interest rates either to remain stable or to decline in the future.

4. A homeowner was considered to have lengthened the maturity if the term on the new mortgage exceeded the remaining term on the former mortgage.
5. Effects of cash-out refinancing on term to maturity and size of monthly mortgage payment, 2001 and 2002 Percent

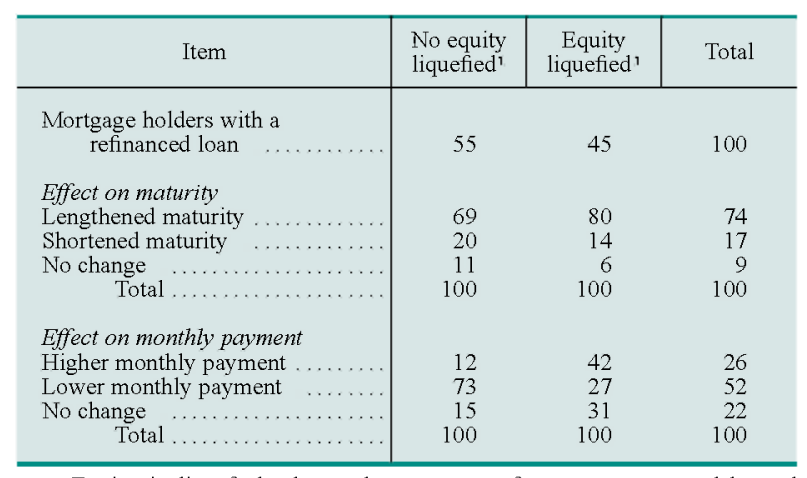

1 Equity is liquefied when a homeowner refinances mortgage debt and borrows more than is necessary to repay the balance on the existing mortgage(s) plus closing costs on the new loan.

and the term of their mortgage lengthened about six years on average (not in table). In contrast, 17 percent had mortgages with a shorter maturity, most of whom chose fifteen-year mortgages, and shortened their maturity by an average of 7,/2 years (not in table). The remainder kept their maturity roughly the same.

A significant portion (45 percent) of homeowners who refinanced in 2001 and the first half of 2002 used the opportunity to liquefy some of their home equity. By comparison, about 35 percent of refinancing homeowners in a similar survey in 1999 liquefied equity (not shown in table). The difference in the proportion of cash-out refinancings in the two surveys may have been due to differences in housing market conditions. Home prices had generally appreciated much more rapidly in the years just before the current wave of refinancings than they had in the early and mid-1990s, and thus homeowners had more equity to tap. In addition, consumer credit, particularly credit card debt, rose sharply in the period between the latest two surveys, creating an incentive to repay relatively expensive consumer debt with less costly mortgage debt.

Changes in maturity in 2001 and 2002 refinancings differed somewhat between those who took cash out and those who did not, with the former group more likely to increase the term to maturity of their loans. Of homeowners who did not liquefy equity, 69 percent lengthened the maturity of their loans, and 20 percent shortened it. Among homeowners who liquefied equity, 80 percent lengthened the maturity on their loans while 14 percent shortened it.

As a result of the changes in interest rates, loan maturities, and amounts owed, 52 percent of homeowners refinancing in 2001 and early 2002 had a lower monthly payment after obtaining the new 
6. Uses of funds liquefied in 2001 and 2002 refinancings Percent except as noted



loan, and 26 percent had a higher payment. In part because they took on additional debt, only 27 percent of homeowners who liquefied equity had a lower monthly payment, compared with 73 percent of homeowners who did not liquefy equity.

\section{Uses of Borrowed Funds}

Equity liquefied in refinancings is used in various ways, including funding home improvements or current consumption, paying down other debts, and changing the mix of a household's assets. For homeowners in the survey who refinanced in 2001 and the first half of 2002, the most common use of funds, reported by 51 percent of those who took out cash, was to repay other debts (table 6). Paying for home improvements was cited by 43 percent of those who took out cash; and making consumer expenditures, such as vehicle purchases, vacations, education, and medical expenses, was cited by 25 percent. Stock market or other financial investment was cited by 13 percent of the group; real estate or business investment, by 7 percent; and tax payments, by 2 percent. These proportions are similar to those in the 1999 survey, although the earlier survey found that the proportion funding consumer expenditures was somewhat higher.

Looking at the uses of funds in terms of dollars rather than proportion of loans gives a somewhat different picture. Refinancers taking cash out spent 35 percent of liquefied equity on home improvements and used 26 percent to pay off other debt. They used 16 percent of the funds for consumer expenditures, 10 percent for real estate or business investments, 11 percent for stock market investments, and 2 percent for taxes. That home improvements are generally large expenditures may explain why they account for a greater share of activity when cash-out usage is measured by dollars rather than by number.
7. Home equity liquefied in refinancings, 2001 and 2002

\begin{tabular}{|c|c|}
\hline $\begin{array}{l}\text { Amount liquefied } \\
\text { (current dollars) }^{1}\end{array}$ & Percent : \\
\hline \multirow[t]{3}{*}{$\begin{array}{l}1-9,999 \quad \ldots \ldots \ldots \ldots \ldots \ldots \ldots \\
10,000-24,999 \\
25,000 \text { or more } \quad \ldots \ldots \ldots \ldots \ldots \ldots \ldots\end{array}$} & $\begin{array}{r}18 \\
43 \\
39 \\
100\end{array}$ \\
\hline & Dollars \\
\hline & $\begin{array}{l}26,723 \\
18,500\end{array}$ \\
\hline
\end{tabular}

1. Amount borrowed through refinancing that exceeded amount due on existing mortgage(s) plus closing costs.

2 Includes only refinancers who liquefied equity

The amounts borrowed through cash-out refinancing in some cases were sizable (table 7). Nearly 40 percent of homeowners who extracted equity in 2001 and the first half of 2002 took out more than $\$ 25,000$. The mean amount liquefied was about $\$ 26,700$, and the median amount was $\$ 18,500$. Both of these amounts are substantially larger than the corresponding figures from the 1999 survey; in that survey, the mean amount was $\$ 18,240$, and the median amount was $\$ 10,000$.

Although some refinancers added significantly to their mortgage debt by liquefying equity, those refinancers who borrowed extra funds ultimately owed, on average, somewhat less mortgage debt than those who did not (table 8). Those refinancers who liquefied equity owed an average of nearly $\$ 126,000$, and those who did not owed roughly $\$ 133,500$. Both

8. Cash-out, amount owed, and loan-to-value ratios among refinancers, 2001 and 2002

Dollars except as noted

\begin{tabular}{|c|c|c|c|}
\hline Item & $\begin{array}{l}\text { No equity } \\
\text { liquefied' }\end{array}$ & $\begin{array}{l}\text { Equity } \\
\text { liquefied' }\end{array}$ & Total \\
\hline \multicolumn{4}{|l|}{ Home value } \\
\hline Mean ..... & 249,366 & 230,704 & 240,800 \\
\hline Median & 175,000 & 170,000 & 175,000 \\
\hline \multicolumn{4}{|l|}{ Cash-out } \\
\hline Mean .. & 0 & $26,577^{\prime}$ & 11,801 \\
\hline Median & 0 & 18,500 & \\
\hline \multicolumn{4}{|l|}{ Amount owed } \\
\hline Mean ....... & 133,484 & 125,931 & $130,017^{2}$ \\
\hline Median & 110,000 & 105,000 & 105,000 \\
\hline \multicolumn{4}{|l|}{ Loan-to-value ratio } \\
\hline Mean (percent) & 60.4 & 62.9 & 61.6 \\
\hline Median (percent) & 62.7 & 65.0 & 63.3 \\
\hline
\end{tabular}

1. Equity is liquefied when a homeowner refinances mortgage debt and borrows more than is necessary to repay the balance on the existing mortgage(s) plus closing costs on the new loan.

2 These figures differ slightly from the comparable amounts shown in some other tables because the estimates in this table are based on a slightly different sample of respondents. 
groups of refinancers appear similar when measured by remaining equity, as both groups had average final loan-to-value ratios near 60 percent.

\section{AN ECONOMETRIC ANALYSIS OF REFINANCING 'AND CASH-OUT}

The surveys sponsored by the Federal Reserve provide an opportunity to use econometric techniques to rank the relative importance of different factors that have influenced refinancing and cash-out activity during the refinancing waves of the past four years. The household's economic and demographic characteristics and its expectations about future interest rates and economic conditions might be important determinants of this activity. ${ }^{5}$

\section{The Decision to Refinance}

As noted, deciding whether and when to refinance a home mortgage requires a balancing of costs and benefits. Using survey data, one can statistically rank the relative importance of various factors that may influence a homeowner's propensity to refinance, including the household's income and mortgage status, demographic characteristics, and expectations for the future. ${ }^{5}$ To increase the precision of the estimated models, we pooled responses from the current survey, which covered refinancings from the beginning of 2001 to the middle of June 2002, and an almost identical survey in the spring of 1999 , covering refinancings from the beginning of 1998 through May 1999.

As described earlier, the primary reason that most homeowners refinance is to reduce their monthly mortgage payment. Our statistical analysis confirms the importance of interest rates in the decision to refinance, showing that the higher a homeowner's

5. Our statistical analysis of the household's decision to refinance is based on the literature developed since the 1980 s that attempts to explain the prepayment of mortgages due to refinancing using household demographic and financial characteristics in these decisions. See Wayne Archer, David Ling, and Gary McGill, "Demographic versus Option-Driven Mortgage Terminations," Journal of Housing Economics, vol. 6 (June 1997), pp. 137-63, and John Clapp, Gerson Goldberg, John Harding, and Michael LaCour-Little, "Movers and Shuckers: Interdependent Prepayment Decisions," Real Estate Economics (June 2001), pp. 411-50. Both articles include reviews of earlier literature.

6. We use a logistic regression to describe a homeowner's propensity to refinance and a "Tobit" regression to describe the amount of equity, if any, extracted by refinancers. Details can be found in appendix B. original mortgage rate, the more likely he or she was to refinance. ${ }^{7}$

A homeowner's income also plays a key role in the decision to refinance. In particular, homeowners with relatively low incomes were less likely to refinance, perhaps because closing costs are relatively more onerous for such households or because their credit histories are more likely to be impaired, reducing their likelihood of qualifying for a new mortgage.

The size of a homeowner's original mortgage also bears importantly on the propensity to refinance. As expected, homeowners with larger mortgages were more likely to refinance because potential interest savings were larger. According to our analysis, the effect of mortgage size is not so strong as that associated with mortgage rates or borrower income, but it is nonetheless important. Further analysis reveals that homeowners with mortgages under $\$ 50,000$ were particularly less likely than others to refinance, perhaps because the transaction costs associated with refinancing a relatively small loan outweighed the potential interest savings.

Board-sponsored surveys over the years have found that, even when interest rates are stable or are rising, refinancings continue to occur, albeit at a much slower pace, and that a large proportion of homeowners who refinance during these periods do so to liquefy the accumulated equity in their homes. However, in a time of relatively low mortgage interest rates (as during the periods covered by the most recent two surveys), a homeowner's desire to cashout may have been only one of many motivations for refinancing. We did not find the amount of available equity, holding constant the other factors (including the mortgage size), to be an important determinant of refinancing, suggesting that the homeowner's loan-tovalue ratio did not influence refinancing. Other specifications of our model, including different measures of the homeowner's loan-to-value ratio, also indicated that this ratio was not an important variable. However, a related variable - whether the homeowner perceived that the house value had increased in the past year - had a positive and significant influence on the propensity to refinance.

Beyond a homeowner's current financial circumstances, his or her expectations about future interest

7. A homeowner's decision to refinance is actually driven by the difference between his or her interest rate on the original mortgage and the prevailing mortgage rate. Unfortunately, for the homeowners who did not refinance, we cannot observe the mortgage rate for which they could have qualified. Thus, we rely only on the level of the interest rate on their original mortgage to approximate their potential interest savings from refinancing. 
rates and the state of the economy bear on the decision to refinance. In the monthly surveys, homeowners were asked whether they believed interest rates would rise, stay the same, or fall. Those who believed that rates would rise were more likely to refinance their mortgage. Similarly, respondents who believed that it was a good time to use credit or to make a major purchase (for example, an automobile or a refrigerator) were more likely to refinance. These respondents might have seen refinancing as an opportunity to borrow additional funds to make such purchases.

When homeowners' income growth is high or their uncertainty about continued employment is low, homeowners may be less likely to refinance to obtain cash to sustain their standard of living. The 1999 survey was conducted during a robust economic period. And even though the 2002 survey was conducted during a period of reduced economic growth, a homeowner's assessment of the likelihood of losing his or her job proved not to be an important determinant for refinancing. During this period, income growth had been bolstered by large tax cuts, and the recession was considered by many to be relatively mild; a stronger link might be observed during a more severe downturn.

We also examined the influence of several other factors that have been cited as significant in a homeowner's decision to refinance. For example, older homeowners are supposedly less likely to refinance because they may have less time to recoup the transaction costs. As another example, white homeowners or those with higher education are sometimes asserted to be more aware of, or have more access to, refinancing opportunities, making them more likely to refinance. Finally, homeowners with adjustablerate mortgages might be expected to switch to fixedrate mortgages during times of relatively low mortgage rates. However, we could not identify a statistically important effect for any of these factors. One demographic variable that does seem to be related to refinancing is the presence of children under 18 years of age in the home. Homeowners with younger children were more likely to refinance, perhaps because they needed to obtain cash to finance home improvements or education expenses.

Some other reasons often cited for refinancing cannot be explored given the information in our survey. For example, homeowners sometimes refinance to change the period over which the mortgage is to be repaid. Some homeowners replace their current mortgage with a shorter-term loan, perhaps intending to have their loan paid offi by the time they retire ${ }^{8}$ Other homeowners (for example, those having difficulty making mortgage or other payment obligations or those anticipating a reduction or disruption in income) may replace their current loan with a longer-term loan to reduce the size of their monthly payments; however, our efforts to proxy for this effect indicated that this reason was not important.

\section{The Decision to Cash-Out}

Many homeowners desire to raise funds by liquefying some of the equity in their homes. In some refinancings, the homeowner both extracts equity and lowers the interest rate on his or her mortgage. Like the decision to refinance, the decision to take cash out and the amount of cash to take out during refinancing can be statistically modeled. We again use the results from the two surveys to construct such a model.

Not surprisingly, a primary determinant of the likelihood that a homeowner will extract equity is the amount of equity in the home. Homeowners with low loan-to-value ratios were more likely to extract equity during a refinancing.

Beyond having equity to liquefy, a few other factors were important in determining the amount of cash to take out. Homeowners reporting that it is a good time to use credit were more likely to take cash out. White homeowners and homeowners with younger children were also more likely to take cash out. Homeowners who believed that they had a higher chance of losing their jobs were less likely to borrow additional money during the refinancing. However, other factors, such as age, education, and income, did not prove to be important in indicating which homeowners were more likely to extract equity during refinancing.

\section{AGGREGATE ESTIMATES OF THE CHANGE IN. MORTGAGE PAYMENTS AND THE USES OF FUNDS}

This section lays out a framework for using the responses from the 2002 survey to assess the possible effects on the macroeconomy of the recent wave of

8. Of course, a homeowner can, in most cases, repay a long-term mortgage over a period shorter than the stated term by making larger payments than are required. In such a case, however, the homeowner would not benefit from the lower interest rates typically available on shorter-term loans. 
home mortgage refinancings. We consider separately the two ways in which a mortgage refinancing may affect a household's resources: first, by changing the stream of future mortgage payments and, second, by providing immediate cash if the household has chosen to liquefy some of its home equity. We also extrapolate from the survey responses on the uses of liquefied equity to gauge how much aggregate spending has been funded through this channel. However, the appropriate interpretations of such calculations are complicated by a variety of factors, as we discuss below.

The survey results provide information about the key determinants of mortgage payments, both before and after refinancing. Before refinancing, the outstanding balance on the average home mortgage that was refinanced between the beginning of 2001 and the middle of 2002 was $\$ 118,092$. In addition, the average original contract interest rate of mortgages in this group, weighted by dollars of outstanding balance, was 8.1 percent, and the dollar-weighted average remaining maturity was twenty-two years.

Refinancing lowered the interest rate of these mortgages to a dollar-weighted average of 6.8 percent. If the maturity and outstanding balance of the average refinanced mortgage had not changed, the decline in the interest rate would have lowered the monthly mortgage payment for the average refinancing homeowner by $\$ 98$, for an annual savings of $\$ 1,179$. Multiplying this annual savings by 11.145 million (the weighted 10.4 percent of the sample that refinanced over the period multiplied by an estimated 107 million households in the United States) yields an aggregate annual decline in mortgage payments of $\$ 13.1$ billion.

The maturity of the average refinanced mortgage (again weighted by dollars of outstanding balance) was twenty-nine months longer than that of the average original mortgage. All else being equal, this lengthening of the maturity also served to lower mortgage payments. Allowing for both the longer maturity and the decline in the mortgage interest rate, the implied average reduction in the mortgage payment was $\$ 135$ monthly, or $\$ 1,621$ annually. This figure suggests an aggregate annual decline in mortgage payments due to both factors of $\$ 18.1$ billion.

Offsetting the effects of lower interest rates and longer maturities on the mortgage payments of refinancers, outstanding balances rose by a substantial amount. The average homeowner who refinanced in 2001 and 2002 (including both those who cashed out and those who did not) reported that the cash received at settlement, after closing costs were paid, was $\$ 11,754$. Adding this amount to the original mortgage balance, along with an additional 2 percent of the balance to proxy for closing costs (an amount commonly cited by industry analysts), the average outstanding balance after refinancing was $\$ 132,443.9$ The combined effect of the lower interest rate, the longer remaining maturity, and the higher balance is to lower the average refinancing homeowner's mortgage payments by $\$ 35$ per month, or $\$ 418$ per year, and aggregate annual mortgage payments by $\$ 4.7$ billion.

Incorporating the associated change in income taxes reduces the savings achieved through refinancing. The estimated $\$ 4.7$ billion reduction in aggregate mortgage payments represents the combination of a $\$ 6.7$ billion decline in mortgage interest payments and a $\$ 2$ billion rise in mortgage principal payments. The decline in mortgage interest payments implies that refinancers who itemize deductible expenses for calculation of taxable income were eligible for appreciably smaller deductions for interest payments and therefore had higher tax liabilities. Although the Survey of Consumers does not have enough information about the tax status of its respondents to allow for a precise estimate of the increment to tax liabilities associated with refinancing, we can do a rough calculation using data from other sources. In 1999, the ratio of home mortgage interest deducted by taxpayers ( $\$ 272$ billion) to total mortgage interest paid by homeowners ( $\$ 328$ billion) was $0.83 .{ }^{10}$ This ratio suggests that the $\$ 6.7$ billion decline in mortgage interest payments was associated with a $\$ 5.6$ billion reduction in home mortgage holders' annual deductions." In addition, federal income tax payments in 1999 were an estimated $\$ 56.9$ billion lower than they

9. This number is slightly different from the number shown in table 1 because for these estimates the survey respondent had to have provided complete information about his or her mortgage amounts and mortgage rates before and after refinancing.

Some of the refinancers who did not liquefy equity may have paid down a portion of their mortgages as part of refinancing. Because our survey results provide no information about such behavior, we assume it does not occur. As a result, our calculation may overstate the increase in the average outstanding balance.

10. The figure for home mortgage interest claimed as a deduction is from David Campbell and Michael Parisi, "Individual Income Tax Returns, 1999," Statistics of Income Bulletin (Fall 2001), pp. 9-47. The estimate of total mortgage interest paid was computed by multiplying the household sector's average mortgage stock of $\$ 4,388$ billion from the U.S. flow of funds accounts by the Bureau of Economic Analysis's average effective interest rate on the stock of mortgage debt of 7.47 percent.

11. This figure may slightly overstate the reduction in deductions because points paid as part of the refinancing transaction can be deducted (after amortizing them over the lifetime of the loan). The survey results do not include information about points, and our calculation makes no allowance for them. 
would have been in the absence of the deduction for home mortgage interest payments. ${ }^{12}$ Dividing this amount by mortgage interest deducted implies that the average marginal federal income tax rate of taxpayers deducting such interest was 21 percent in 1999. ${ }^{13}$ Assuming that this marginal federal income tax rate applied to homeowners who refinanced their mortgages in 2001 and the first half of 2002 and further assuming that their marginal state income tax rate was 5 percent, the increase in tax payments associated with the refinancings would be $\$ 1.5$ billion annually. Taking the difference between the aggregate annual reduction in mortgage payments associated with the refinancings and this figure implies that the additional tax liabilities would offset close to one-third of refinancers' aggregate annual savings from lower mortgage interest payments, putting aggregate annual savings net of income taxes at $\$ 3.2$ billion.

Turning to the immediate increase in the cash resources of the refinancers who liquefied home equity in 2001 and the first half of 2002, the average amount of equity withdrawn by these households was $\$ 26,723$ (table 7). Multiplying this figure by 4.92 million (the weighted 4.6 percent of the sample that refinanced and liquefied equity over the period multiplied by an estimated 107 million households in the United States) yields an aggregate estimate of funds raised through cash-out refinancings of $\$ 131.6$ billion.

As described earlier, these funds were reportedly used in different ways, and we can use the ratios reported in the second column of table 6 to estimate the aggregate counterparts of these uses. ${ }^{14}$ For the nation as a whole, the survey results suggest that $\$ 20.7$ billion of the liquefied equity was used to fund purchases that are classified in the national accounts as personal consumption expenditures (PCE), such as spending on vehicles, other consumer goods, vacations, education, and medical services. An estimated $\$ 46.3$ billion was spent on home

12. See Analytical Perspectives, Budget of the United States Government, Fiscal Year 2001, p. 109.

13. Federal income tax rates have fallen a bit since 1999 , but we cannot do these calculations for a later year because information about the amount of home mortgage interest deducted is available only through 1999. However, we obtain a similar estimate for the average marginal federal income tax rate of mortgage holders if we divide the estimated cost of the deduction for 2001 (from the most recent Budget of the United States Government) by the product of the average mortgage interest paid for 2001 and the ratio of deductions to total mortgage interest paid in 1999.

14. As noted above, the number of respondents for each reported use of funds is quite small. As a result, the estimates in this paragraph are not precise. improvements; most of these expenditures probably fall in the residential investment category of the national income accounts, but the expenditures may also include items such as carpeting, draperies, or kitchen appliances that would be counted as part of PCE. Refinancers also used an estimated $\$ 28.1$ billion to pay down nonmortgage debt and $\$ 5.8$ billion to pay off second mortgages. Of the remaining liquefied equity, most (an estimated $\$ 27.5$ billion) was invested in financial assets, real estate, or businesses.

Estimates of the change in households' mortgage payments or of the amount of housing equity liquefied, however, are only part of the information necessary to assess the effects of refinancing activity on the macroeconomy. Another consideration is the effect of refinancing on mortgage investors. ${ }^{15}$ The reduction in mortgage interest payments leads to a decline in the amount of interest income received by these investors. As a result, the propensity to consume of the typical refinancing household must be higher than that of the typical mortgage investor for lower mortgage payments to have a positive effect on aggregate spending.

Even if one considers only the refinancers, the amount of incremental spending - that is, the amount above that which would have occurred in the absence of the refinancing - is unclear. A simple model of consumer behavior assumes that households are rational, can borrow all they want, and know their wealth and future income with certainty. Given these assumptions, refinancings generate new consumption because a reduction in the mortgage interest rate increases household wealth. ${ }^{16}$ In particular, the increase in wealth associated with lower mortgage payments would be the present discounted value of the reduction in payments over the lifetime of the mortgage loan, holding the maturity and the outstanding balance constant and assuming the household discounts cash flows at a rate not perfectly correlated with its current mortgage rate. In addition, the ability to liquefy home equity through mortgage refinancing

15. Investors in mortgages include both individuals and institutions such as pension funds and life insurance companies. Although institutions do not consume directly, most of the income associated with the mortgages they hold ultimately passes through to the household sector through dividends and through increases in the value of the firms. The only portion of the savings of mortgage borrowers that does not have a negative effect on the wealth of U.S. mortgage investors is the small amount associated with mortgage debt that is held by foreigners either directly or indirectly through institutions.

16. The term "consumption" is used broadly in this discussion. The arguments are meant to explain not only households' behavior regarding the items included in the consumer expenditures category in table 6 but also their behavior associated with the home improvements category. 
provides households with the opportunity to fund desired consumption by borrowing at the mortgage rate, which is typically lower (especially on an aftertax basis) than the rates on other types of loans. In this case, the gain in household wealth would be the difference between the cost of funding consumption by liquefying equity and the cost of an alternative source of funds.

Other assumptions are consistent with the view that refinancing spurs greater amounts of additional consumption among mortgage borrowers. For example, homeowners may be rational and unconstrained but uncertain about the value of their homes because of the costs associated with acquiring such information. The appraisal that accompanies a refinancing may raise a homeowner's own estimate of the home's value, which, in turn, raises his or her perceived wealth. The amount of home equity liquefied may reflect this apparent windfall so that the new spending funded by the equity could be substantial.

Yet another possibility is that households may be aware of increases in their home value but face self-control problems. Because capital gains on housing before a refinancing are relatively illiquid, households are unlikely to consume them. However, when the opportunity to refinance arises (because, for example, mortgage rates have declined), households can convert their gains to a liquid form. Again, in this case, a large portion of liquefied equity may go toward new consumption by refinancers.

Finally, the current consumption of some households may fall materially short of their desired consumption given their expectations of future income growth. Such a gap could arise if these households anticipate significantly higher income than they are currently receiving, if they have no liquid financial assets, and if they cannot obtain unsecured debt. After a period of rapid appreciation of house prices, cash-out refinancing transactions may allow these formerly liquidity-constrained households to gain access to their accumulated capital gains and thereby permit them to significantly increase their spending.

Distinguishing among these alternative possibilities regarding the effect of refinancing on spending is difficult. A large body of economic literature suggests that, though some consumers are rational, fully aware of their available resources, and not liquidity constrained, other consumers are different. Observing a high correlation between refinancing transactions and spending does not resolve the issue, because heightened refinancing activity may simply reflect the means by which households are choosing to finance spending that is induced by changes in other factors. For example, homeowners who receive posi- tive news about their future income prospects may increase their consumption today and, further, may fund that spending by extracting accumulated home equity; in this case, mortgage refinancing is not the cause but only the means of higher spending.

Despite these uncertainties, we attempt to put an upper bound on the direct effect of refinancings on aggregate demand. We first note that the average respondent in our sample was surveyed at the end of March 2002 and was asked for details about refinancing activity over the preceding fifteen months (that is, since January 2001). ${ }^{17}$ We also assume that this average refinancer experienced lower mortgage payments for half of these fifteen months; given annual aggregate mortgage payment savings (net of taxes) of $\$ 3.2$ billion, the average savings between January 2001 and March 2002 would be \$2 billion. We also assume that refinancing households used all these savings to pay for items classified as PCE in the national income accounts and that mortgage investors have no response to the reduction in interest they receive. Finally, we assume that this spending plus the $\$ 20.7$ billion of PCE funded by liquefied equity that we discussed earlier represents incremental spending.

Under these extreme assumptions, the recent wave of mortgage refinancing added $\$ 22.7$ billion to PCE between January 2001 and March 2002. On an annual basis, the increment would be $\$ 18.1$ billion. This amount represents $; 4$ percent of average annual PCE ( $\$ 7,024$ billion) over the period. ${ }^{18}$ Positing that half the liquefied equity that reportedly funded home improvements was spent instead on items included in PCE would raise the estimated maximum increment to $\mathrm{PCE}$ to is percent.

Our estimate of an upper bound for the percentage contribution of refinancing activity to residential investment is larger than that for PCE, mainly because residential investment spending is small relative to PCE. The estimated $\$ 46.3$ billion of liquefied equity that refinancers reported using to fund home improvements over the fifteen-month reference period corresponds to an annual figure of $\$ 37$ billion. Comparing this amount with the $\$ 448$ billion average annual level of residential investment over the period, an upper bound for the contribution of refinancing

17. The use of the end-of-March date will yield inaccuracies in our estimates to the extent that refinancing activity was not distributed evenly over the six months in which households were sampled. However, we believe that any such error would be small, and thus our calculations ignore it.

18. Calculating the contribution of refinancing activity to the growth rate of PCE is not possible because we do not know how much refinancing added to the level of PCE in earlier periods. 
activity to the level of residential investment is 8.3 percent.

The survey results also provide evidence about the influence of refinancing activity on some key aggregate financial statistics. For example, the $\$ 132$ billion of home equity liquefied in 2001 and early 2002, net of the $\$ 5.8$ billion estimated to have been used to pay down second mortgages, can account for 20 percent of the $\$ 616$ billion growth in the home mortgage stock between the beginning of 2001 and March 2002. Further, the actual increase in consumer (nonmortgage) credit between the beginning of 2001 and March 2002 was $\$ 131$ billion, corresponding to an annual rate of increase of 6.6 percent. If households had not used an estimated $\$ 28.1$ billion of liquefied equity to pay down nonmortgage debt over the period, consumer credit would have expanded at an average annual rate of 8 percent.

\section{SUMMARY}

Over the past ten years, millions of homeowners have taken advantage of lower mortgage interest rates and higher home values and have refinanced their mortgage loans. For many, the decision to refinance was motivated by a desire to reduce their monthly mortgage payments, either by obtaining a lower interest rate or by extending the maturity of their mortgage. According to the University of Michigan's Surveys of Consumers, most homeowners who refinanced their mortgages in 2001 and early 2002 did lower their mortgage rates, and a significant proportion also borrowed additional funds by taking out a new mortgage that was larger than the outstanding balance on their former mortgage plus closing costs. A large proportion of homeowners who cashed out equity from their homes used these funds for home improvement or the repayment of other debts. This boom in cash-out refinancing activity has likely boosted consumption spending materially over the period covered by the survey, though the magnitude of the effect of such transactions on consumption spending is difficult to estimate.

\section{APPENDLX A: THE SURVEY OF CONSUMERS}

To obtain information on the prevalence in the United States of residential mortgage refinancings by homeowners, the extent to which refinancings are used to liquefy accumulated equity, and the uses of the liquefied funds, the Federal Reserve Board sponsored questions that were included in the Surveys of Consumers for January 2002 through June 2002. The Survey Research Center at the University of Michigan conducted the nationwide surveys.

Interviews were conducted by telephone, with telephone numbers drawn from a cluster sample of residential numbers. The sample was chosen to be broadly representative of the four main regions of the country-Northeast, North Central, South, and West - in proportion to their populations. Alaska and Hawaii were not included. For each telephone number drawn, an adult in the family was randomly selected as the respondent. The survey defines a family as any group of persons living together who are related by marriage, blood, or adoption or any individual living alone or with a person or persons to whom the individual is not related.

Together, the six surveys sampled 3,003 families, 2,240 of whom were homeowners. Among the homeowners, 1,378 had an outstanding mortgage or land contract, and 691 of this group reported that their outstanding first mortgage was a refinanced loan. Among the homeowners who had refinanced, 305 had refinanced in 2001 or the first half of 2002. The survey data have been weighted to be representative of the population as a whole, thereby correcting for differences among families in the probability of their being selected as survey respondents. All survey data in the tables are based on weighted observations.

Estimates of population characteristics derived from samples are subject to error, with the amount of the error dependent on the extent to which the sample respondents differ from the general population. Table A.1 indicates the sampling errors for survey results derived from samples of different sizes.

A.1. Approximate sampling errors for survey results, by size of sample Percentage points

\begin{tabular}{|c|c|c|c|c|c|}
\hline \multirow{2}{*}{$\begin{array}{l}\text { Survey result } \\
\text { (percent) }\end{array}$} & \multicolumn{5}{|c|}{ Size of sample } \\
\hline & 100 & 300 & 1,000 & 1,500 & 3,000 \\
\hline & 11.2 & 6.5 & 3.5 & 2.9 & 2.0 \\
\hline 30 or 70 & 10.3 & 5.9 & 3.2 & 2.6 & 1.9 \\
\hline 20 or 80 & 9.0 & 5.2 & 2.8 & 2.3 & 1.6 \\
\hline 10 or 90 & 6.7 & 3.9 & 2.1 & 1.7 & 1.2 \\
\hline 5 or 95 & 4.9 & 2.8 & 1.5 & 1.3 & 9 \\
\hline
\end{tabular}

NoTE. 95 percent confidence level, 1.96 standard errors. 


\section{APPENDIX B: STATISTICAL ANALYSIS OF REFINANCING 'AND CASH-OUT}

This appendix presents the results of our estimated refinancing and cash-out regressions, used in the text for the discussion of the propensity to refinance and to extract home equity during refinancing. Table B.1 describes the logistic regression used to estimate a homeowner's probability of refinancing. Table B. 2 describes the Tobit regression used to estimate the expected amount of cash extracted during refinancing.

B.1. Logistic regression used to estimate homeowner's probability of refinancing

\begin{tabular}{|c|c|c|c|}
\hline Variable' & Change in variable & $\begin{array}{l}\text { Marginal effect } 2 \hat{2} \\
\text { (percent) }\end{array}$ & $\begin{array}{l}\text { Statistically } \\
\text { significant }\end{array}$ \\
\hline Original mortgage rate & $\begin{array}{l}\text { Increase the original mortgage rate by } 2.9 \text { percentage points } \\
\text { (one standard deviation) }\end{array}$ & 23.3 & yes \\
\hline Original mortgage amount less than $\$ 50,000$ & From a mortgage greater than to a mortgage less than $\$ 50,000$ & -10.8 & yes \\
\hline Respondent from the Midwest & From not being to being from the Midwest & 4.1 & yes \\
\hline Surveyed in 1999 & From surveyed in 2002 to surveyed in 1999 & -3.8 & yes \\
\hline Original mortgage amount . & $\begin{array}{l}\text { Increase original mortgage amount by } \$ 92,148 \text { (one standard } \\
\text { deviation) }\end{array}$ & 3.5 & yes \\
\hline Interest rate expectations & $\begin{array}{l}\text { From expecting rates to go down or stay the same to expecting } \\
\text { them to rise }\end{array}$ & 3.1 & yes \\
\hline Children under 18 in the home. & $\begin{array}{l}\text { From not having to having at least one child under } 18 \text { living at } \\
\text { home }\end{array}$ & 2.3 & yes \\
\hline House value change over the last year & $\begin{array}{l}\text { From believing that the value of the house stayed the same or } \\
\text { went down in the last year to believing that it went up }\end{array}$ & 1.9 & yes \\
\hline Income greater than $\$ 40,000$ & From income less than to income greater than $\$ 40,000$ per year & 1.4 & yes \\
\hline Good time to buy durables & $\begin{array}{l}\text { From believing it is a bad or neutral time to buy durables } \\
\text { to believing it is a good time }\end{array}$ & 1.1 & yes \\
\hline Respondent not white & From white to nonwhite & -4.0 & no \\
\hline Respondent from the West & From not being to being from the West & 2.8 & no \\
\hline Age greater than 55 & From age less than to age greater than 55 & 2.0 & no \\
\hline Original mortgage had variable rate... & From not having to having a variable rate on the original mortgage & 2.0 & no \\
\hline Loan-to-value ratio greater than 90 percent & From having ratio less than to having ratio greater than 90 percent & .7 & no \\
\hline Education beyond high school & From not having to having education beyond high school & -.4 & no \\
\hline Respondent from the Northeast & From not being to being from the Northeast & -.4 & no \\
\hline Equity & Increase equity by $\$ 156,400$ (one standard deviation) & -.3 & no \\
\hline Probability of losing job in next year & $\begin{array}{l}\text { Increase probability of losing job in the next year by } 25 \text { percent } \\
\text { (one standard deviation) }\end{array}$ & -.1 & no \\
\hline $\begin{array}{l}\text { 1. Variables are first grouped by whether the } \\
\text { then ranked by the estimated size of the margin } \\
\text {. The marginal effect is the difference } \\
\text { probability of refinancing for all respondents in } \\
\text { changed and the average estimated probability } \\
\text { in the sample without the change. For example, }\end{array}$ & $\begin{array}{l}\text { probability of refinancing between } \\
\text { whites in the sample as if they we } \\
\text { constant, and then calculate the av } \\
\text { all respondents given this change } \\
\text { change from this calculated probal } \\
\text { the column. }\end{array}$ & $\begin{array}{l}\text { white and nonwhite } \\
\text { e nonwhite, holdin } \\
\text { rage estimated prob } \\
\text { We subtract the sar } \\
\text { ility of refinancing }\end{array}$ & $\begin{array}{l}\text { ndents, we tre } \\
\text { ther character } \\
\text { of refinancir } \\
\text { verage witho } \\
\text { the result sho }\end{array}$ \\
\hline
\end{tabular}


B.2. Tobit regression used to estimate expected cash extracted during refinancing

\begin{tabular}{|c|c|c|c|}
\hline Variable ${ }^{1}$ & Change in variable & $\begin{array}{l}\text { Marginal effect" } \\
\text { (dollars) }\end{array}$ & $\begin{array}{l}\text { Statistically } \\
\text { significant }\end{array}$ \\
\hline Respondent not white & From white to nonwhite & $-5,537$ & yes \\
\hline Surveyed in 1999 & From surveyed in 2002 to surveyed in 1999 & $-4,426$ & yes \\
\hline Children under 18 in the home & $\begin{array}{l}\text { From not having to having at least one child under } 18 \text { living } \\
\text { at home }\end{array}$ & 4,143 & yes \\
\hline Good time to use credit & $\begin{array}{l}\text { From believing it is a bad or neutral time to use credit } \\
\text { to believing it is a good time }\end{array}$ & 2,272 & yes \\
\hline Original loan-to-value ratio $\ldots . . .$. & $\begin{array}{l}\text { Increase ratio of original mortgage by } 22 \text { percent (one standard } \\
\text { deviation) }\end{array}$ & -265 & yes \\
\hline Probability of losing job in next year & $\begin{array}{l}\text { Increase probability of losing job in the next year by } 24 \text { percent } \\
\text { (one standard deviation) }\end{array}$ & -78 & yes \\
\hline Finances better one year from now & $\begin{array}{l}\text { From believing finances will be worse or the same in a year } \\
\text { to believing they will be better }\end{array}$ & $-2,003$ & no \\
\hline Education beyond high school & From not having to having education beyond high school & 1,883 & no \\
\hline Income greater than $\$ 40,000$ & From income less than to income greater than $\$ 40,000$ per year & 1,847 & no \\
\hline Respondent from the West & From not being to being from the West & $-1,557$ & no \\
\hline House value change over the last year & $\begin{array}{l}\text { From believing that the value of the house stayed the same or } \\
\text { went down in the last year to believing that it went up }\end{array}$ & -671 & no \\
\hline Respondent from the Midwest & From not being to being from the Midwest & 372 & no \\
\hline Respondent from the Northeast & From not being to being from the Northeast & -314 & no \\
\hline Age of respondent & Increase age of respondent by 11 years (one standard deviation) & 97 & no \\
\hline
\end{tabular}

